Overall the book has a certain appeal of its own, and there is an astonishing amount of information in a small space. In the words of one paediatric house officer, 'it is easily nursed'.

Learning Disorders in Children: Diagnosis, Medication, Education. Edited by L. TARNOPOL. (Pp. xvii +366 ; tables and figures. £4.75.) Edinburgh: Churchill Livingstone. 1971.

'Learning disabilities now constitute the most pervasive medical problem of children in the United States . . . (affecting) between 5 and $20 \%$ of the nonretarded child population.' This opening statement from the Editor's Introduction gives the background to this book, and to the increasing involvement of paediatricians in problems of this kind. 16 authors contribute to the 9 chapters, 4 of which were part of a symposium and 5 written subsequently. Not surprisingly the book is something of a patchwork of varied quality.

Perhaps the most successful chapter is that by Dr. S. D. Clements and colleagues from Little Rock on 'Two cases of Learning Disabilities'. These children are presented in such a way as to illuminate the whole problem of learning disorders, and how they can be assessed and managed.

What will surprise most British paediatricians is the emphasis given to the use of drugs in learning disorders. 6 of the 9 chapters are on medication, including an 86-page transcript of a discussion (which would have benefited from further editorial shortening and summarizing). The final chapter by Dr. L. J. Whitsell on Clinical Pharmacology of Psychotropic Drugs is, by contrast, a masterly and valuable short summary with an excellent annotated bibliography.

The British paediatrician concerned with learning problems in children-and there are few who should not be-will find a good deal of interest in this book. He will probably not recommend it to beginners in this field, because the emphasis on medication differs so much from normal British paediatric practice. But he must be left asking the tantalizing question of whether we use the central stimulants, the tranquillizers, and the antidepressants, too little in the treatment of these children, or whether our American colleagues use them too much.

The Biochemistry of Development. Edited by P. F. Benson and R. A. MCCANCE. (Pp. v + 273; illustrated. £3.25.) Philadelphia: Lippincott; London: Heinemann. 1971. 42

In the preface to this book Professor R. A. McCance writes that, 'Some paediatricians will not find this book easy to read'-I would say that most of us will find it difficult but fascinating and some will feel that 'they are not prepared to move with the times'. Having said this I must emphasize that this is an excellent publication of high standard which will be of considerable benefit to units concerned with human development, both fetal and postnatal, with the care of premature, immature, and sick infants and with metabolic research into disorders in early infancy.

The scope of the book is wide, and it is unlikely that many clinicians will be conversant with all the concepts and biochemical advances detailed in the text. With the aid of the numerous references after each chapter it will be a good book to turn to when considering certain developmental situations in the fetus and the newborn baby.

There are ten chapters covering aspects of development ranging from the regulation of liver function during development (Serini and Principi) to Autocoids in Ontogenesis (Mitchell and Porter). The discussion on 'Intrauterine diagnosis and antenatal detection of inherited disease' (Nyhan) underlines the possibilities and the present limitations in the use of these techniques and demonstrates that the availability of human fetal material in culture in the form of cells derived following amniocentesis provides a real opportunity for the study of human development.

The editor (Philip Benson) has contributed a thoughtful section on the Regulation of Genetic Expression including details of some of his own work; and Neils Raiha writes about ornithine and arginine metabolism, describing the development of the mechanisms for the conversion of ornithine to glutamate, polyamines, and creatine, as well as the development of the urea cell enzymes. Ralph Brinster gives a clear description of the biochemistry of the preimplantation period in the mouse and suggests that this information can reasonably be extrapolated to human embryos.

The remaining chapters are concerned with the development of enzymes for carbohydrate metabolism (D. G. Walker) which is clear and concise, changes in human haemoglobins (Huehns and Beaven), and genetic polymorphism (Adinolfi).

Finally there is a long and detailed chapter on lipid metabolism (N. B. Myant) which includes sections on lipids in postnatal brain development and certain developmental disorders of lipid metabolism.

Issues in Human Development. An Inventory of Problems, Unfinished Business and Directions for Research. Scientific editor: VICTOR C. VAughan, III. Symposium sponsored by Temple University, St. Christopher's Hospital for Children, and The National Institute of Child Health and Human Development. (Pp. $x+217$; tables and figures. U.S. \$1.75.) Washington, D.C.: Superintendent of Documents, U.S. Government Printing Office.

In November 1967, some 150 scientists drawn from the biological and social sciences met for four days in Philadelphia to discuss some of the wider aspects of their own subjects. This is the (somewhat belated) record of that symposium, and the editor (Victor C. Vaughan, a paediatrician) states in his preface that: 'The goal of the conference was not so much to reveal answers to problems as to make sure the right questions were being asked, the ultimate answers to which might serve as guides to social and political action. Attention was given in turn to the earliest environmental influences 
on human development, to physical growth and development, to socialization, to cognition and learning, to adolescence, to the urban environment, and to the import of institutions, economics, and the law upon human development.'

One has the impression that had one been present and heard some of the addresses, these might have possessed an inspirational quality, which must have evaporated with the translation into cold print. As it is, the very general terms in which most speakers framed their contributions mitigated against their making much impact in the present publication.

For the paediatrician, the section of Physical and Chemical Growth and Development is perhaps likely to prove the most interesting, giving him an idea of the light that can be shed on human somatic growth, both optimal (and the meaning of this was debated) and deficient, from animal observations.

\section{Referees 1971}

The Editors rely increasingly on the help they receive from those who referee papers, a responsible and onerous, but thankless task. They take this opportunity of acknowledging the services of the following over the past year.

\author{
Charlotte M. Anderson \\ J. Apley \\ G. C. Arneil \\ D. Barltrop \\ T. M. Barratt \\ P. F. Benson \\ B. Billing \\ R. E. Bonham Carter \\ P. T. Bray \\ A. H. Cameron \\ J. S. Cameron \\ Nina A. J. Carson \\ C. O. Carter \\ C. Chantler \\ A. R. Chrispin \\ A. E. Claireaux \\ Barbara E. Clayton \\ K. W. Cross \\ Pamela A. Davies
}
G. M. Komrower
B. Laurence
D. Lawson
B. Levin
J. Lister
June Lloyd
R. A. McCance
R. C. Mac Keith
W. A. Marshall
F. J. W. Miller
R. D. G. Milner
D. Morley
N. B. Myant
J. Nagington
G. A. Neligan
H. H. Nixon
C. O. Ounsted
P. Polani

J. R. Hobbs

A. Holzel

T. T. S. Ingram

R. S. Jones
P. Pinkerton

M. Purves

E. O. R. Reynolds

K. B. Rogers Mary Sheridan Jean Smellie R. W. Smithells J. F. Soothill Rosemary Stephens J. B. P. Stephenson J. M. Tanner

B. Wharton

R. H. R. White J. S. Wigglesworth A. W. Wilkinson J. Wilson

O. H. Wolff

B. S. B. Wood 